\title{
Strategies for Household Water Supply Improvement with Rainwater Harvesting
}

\author{
Tulinave Burton Mwamila ${ }^{1}$, Zacharia Katambara ${ }^{2}$, Moo Young Han ${ }^{3}$ \\ ${ }^{1}$ Department of Rural Water Supply, Ministry of Water and Irrigation, Dar es Salaam, Tanzania \\ ${ }^{2}$ Department of Built Environment Engineering, Mbeya University of Science and Technology, Mbeya, Tanzania \\ ${ }^{3}$ Department of Civil and Environmental Engineering, Seoul National University, Seoul, South Korea \\ Email: ${ }^{\star}$ mtulinave@gmail.com
}

How to cite this paper: Mwamila, T.B., Katambara, Z. and Han, M.Y. (2016) Strategies for Household Water Supply Improvement with Rainwater Harvesting. Journal of Geoscience and Environment Protection, 4, 146158.

http://dx.doi.org/10.4236/gep.2016.49011

Received: August 9, 2016

Accepted: September 26, 2016

Published: September 29, 2016

Copyright $\odot 2016$ by authors and Scientific Research Publishing Inc. This work is licensed under the Creative Commons Attribution International License (CC BY 4.0).

http://creativecommons.org/licenses/by/4.0/

\begin{abstract}
There are significant household water supply challenges including quantity sufficiency and quality, which have economic and social implications. The challenges have remained despite the efforts of government establishing centralized or groundwater systems, and/or having individual crude systems. A Tanzanian rural household case study was considered by assessing the performance of a currently relied surface runoff collecting pond system for domestic purposes. A daily water balance model was applied with performance parameters, no water days (NWD) and rainwater usage (RUR). Rooftop runoff harvesting system was proposed as a water supply source in addition to the current one. Under such dual supply conditions, users can meet the drinking and non-drinking demand even in dry seasons at a minimum of 2 and 20 L/person/d, respectively. For rainwater harvesting adoption (considering selected regions), it was further established that amount and variation in rainfall impacts on quantity available for meeting demand. Increased catchment implies increased harvestable quantity, and with same storage higher reduction of number of NWD although with slight decrease of RUR. Also, increased storage is required for achieving higher RUR in case the same demand is maintained. But same storage can be maintained for increased demand relative to catchment size. However, rainwater catchment increase has greater impact on meeting a specified demand under given condition of rainfall quantity and variation. The RWH technology strategies presented in this study are replicable in other developing countries under site specific conditions.
\end{abstract}

\section{Keywords}

Dual Water Supply, Household Water Supply, Rainwater Harvesting Strategies, Rainwater Harvesting Technology, Tanzania 


\section{Introduction}

A third of the Africa's population, is living in a water scarcity situation. To address this, the Africa Water Vision 2025 was established, which highlighted that underdevelopment and low water resources usage in Africa was due to poor financing and technology but not inadequacy of available water resources. Rainwater harvesting (RWH) has low cost and is capable of performing with low technology and in a decentralized manner.

Even though Tanzania, an eastern African country (Figure 1) is recognized with abundant annual renewable water resources of approximately $89 \mathrm{~km}^{3}$ [1] and annual rainfall ranging from 400 to $2000 \mathrm{~mm}$, the country still suffers water shortages. Low drinking water service coverage, which is $40 \%$ and $74 \%$ in rural and urban areas, respectively [2].

Efforts to address water supply problems and challenges in Tanzania have included centralized systems which have high operation and maintenance cost, and are limited to urban areas. Community based groundwater systems which include springs and wells, which also have problems including water point malfunctioning, limited supply chain and overexploitation of sources. Individual crude systems have challenges of low water quality, insufficient quantity as well as poor infrastructures.

Springs are the highest sought water supply source type, followed closely by shallow wells, and then boreholes, but rainwater harvesting (RWH) is one of the least sought [4]. In a GIS based RWH potential study, [5] established that harvestable rainwater for the medium rainfall $(400-1200 \mathrm{~mm})$, high population ( $>100$ persons $/ \mathrm{km}^{2}$ ) rooftop domain ranges from 115.6 to $346.8 \mathrm{~km}^{3}$ (which generally displays high ability to meet daily water demand), and occupies $38.3 \%$ of the country area.

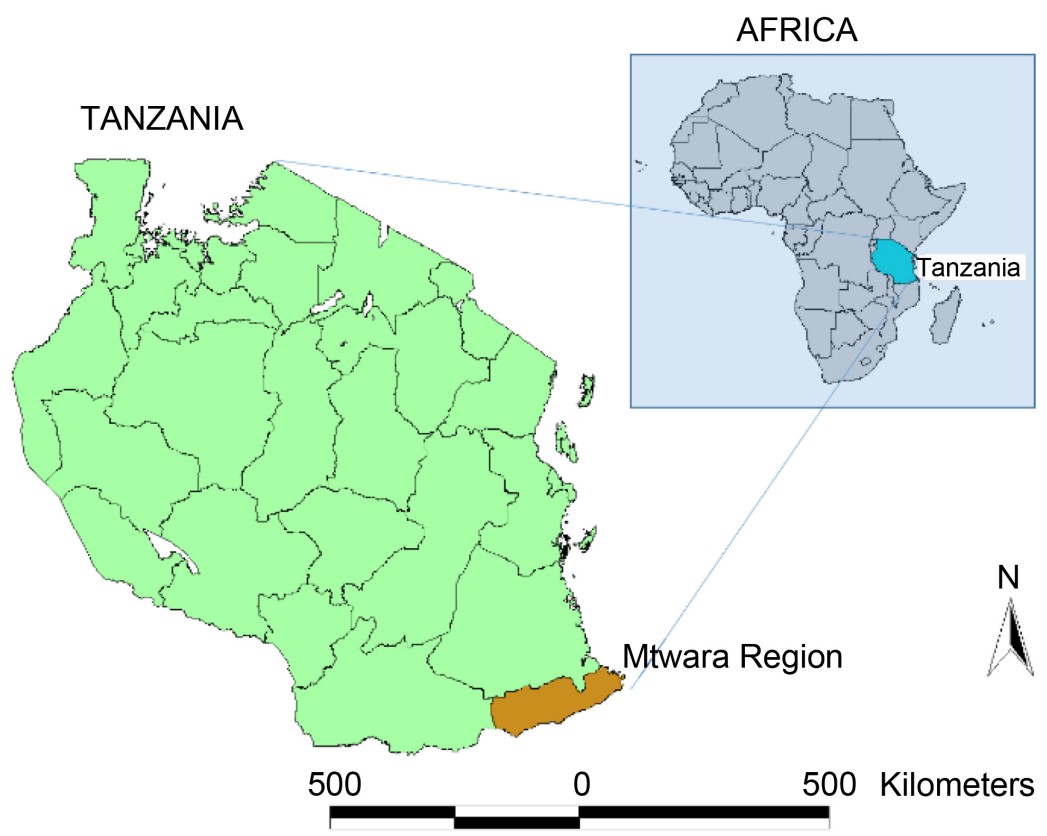

Figure 1. Location map of Tanzania and its regions (Modified from [3]). 
$\mathrm{RWH}$ is a potential and sustainable alternative water source to solve water shortage problems, in particular, in developing countries [6] [7]. With simple strategies rainwater can meet demand even during the dry season [8] [9]. Rainwater quality can meet Tanzania and WHO standards with simple techniques including those of particle load reduction, which may have resulted from the type and conditions of collection, delivery, and storage facilities [10]-[16]. Further, the challenge of investment cost has been addressed through strategies of promoting self-supply and funding initiatives including micro-financing [17] [18].

The objectives of this study are as follows: 1) establishing rooftop RWH potential to improve household water supply; 2) suggest strategies for better water supply practice with adoption of rooftop RWH in Tanzanian regions.

\section{Methodology}

The analysis was performed using a simple daily water balance model with an overall cumulative water storage Equation (1). This incorporates the performance parameters for dry season quantification, NWD, RUR, and WL (Equations (2) (3) and (4a)), defined by [9]. The authors considered all 365 days of the year, even though the site is a day school. Average daily rainfall data were used (Figure 2). Both fixed and variable demand conditions were considered. Variable demand was considered under water level monitoring strategy, Equation (4b) [8]. Equations (5) and (6) are the basic demand conditions.

$$
\begin{gathered}
V_{t}=V_{t-1}+Q_{t}-Y_{t}-O_{t} \\
N W D=\frac{T-\sum_{t=1}^{T} W D}{T} \times 100 ; \\
R U R=\frac{\sum_{t=1}^{T} Y_{t}}{\sum_{t=1}^{T} Q_{t}} \times 100
\end{gathered}
$$

(a) $\quad W L_{t-1}=\frac{V_{t-1}}{S} \times 100 ;$ (b) $D_{t}=f\left(W L_{t-1}\right) ; W L_{t-1}=0 \%, \cdots, 100 \%$

$D_{t}$ is a fixed value

For: $0<V_{t} \leq S ; V_{t}>S$

$$
Y_{t}=D_{t} ; O_{t} \geq 0
$$

For: $V_{t}<0 ; V_{t}=0$

$$
Y_{t}<D_{t} ; Y_{t}=V_{t-1}+Q_{t} ; O_{t}=0
$$

where, $Q_{t}$ is the rainwater harvested on the $t^{t h}$ day; $V_{t-1}$ is the stored rainwater in the tank at the beginning of the $t^{t h}$ day; $D_{t}$ is the daily rainwater demand on the $t^{\text {th }}$ day; $Y_{t}$ is the rainwater supplied during the $t^{\text {th }}$ day; $W D$ is a day on which the demand is fully met; $T$ is the total number of days in a year; $V_{t}$ is the cumulative water stored in the rainwater tank after the end of the $t^{\text {th }}$ day; $O_{t}$ is the overflow amount on the $t^{\text {th }}$ day; $W L_{t-1}$ is the water level percentage in the tank at the beginning of the $t^{\text {th }}$ day; and $S$ is the storage capacity. 


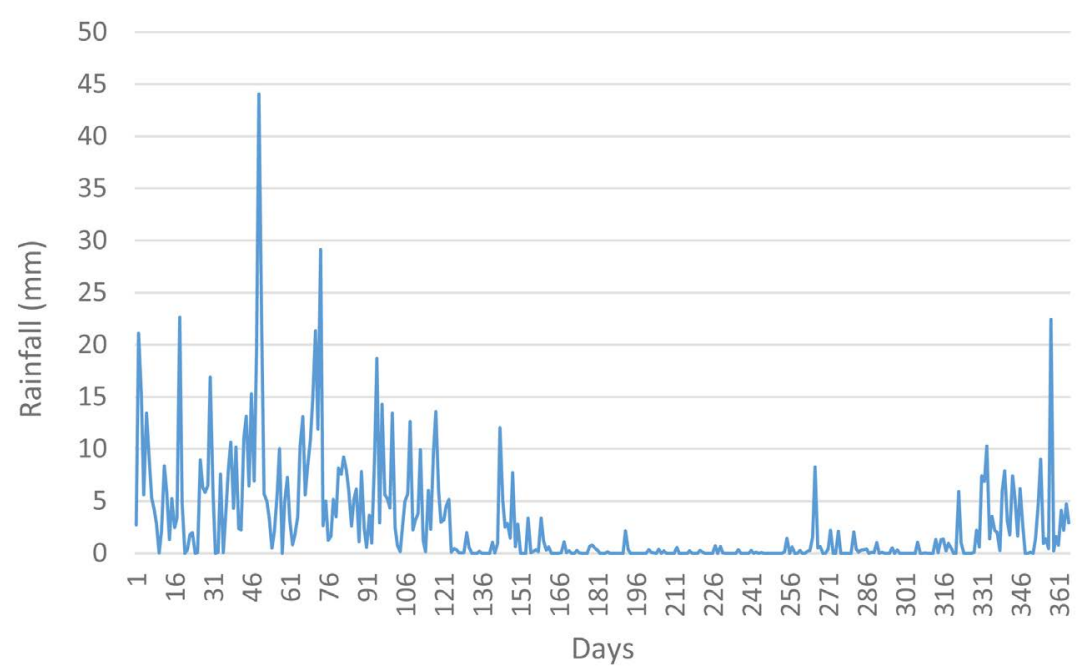

(a)

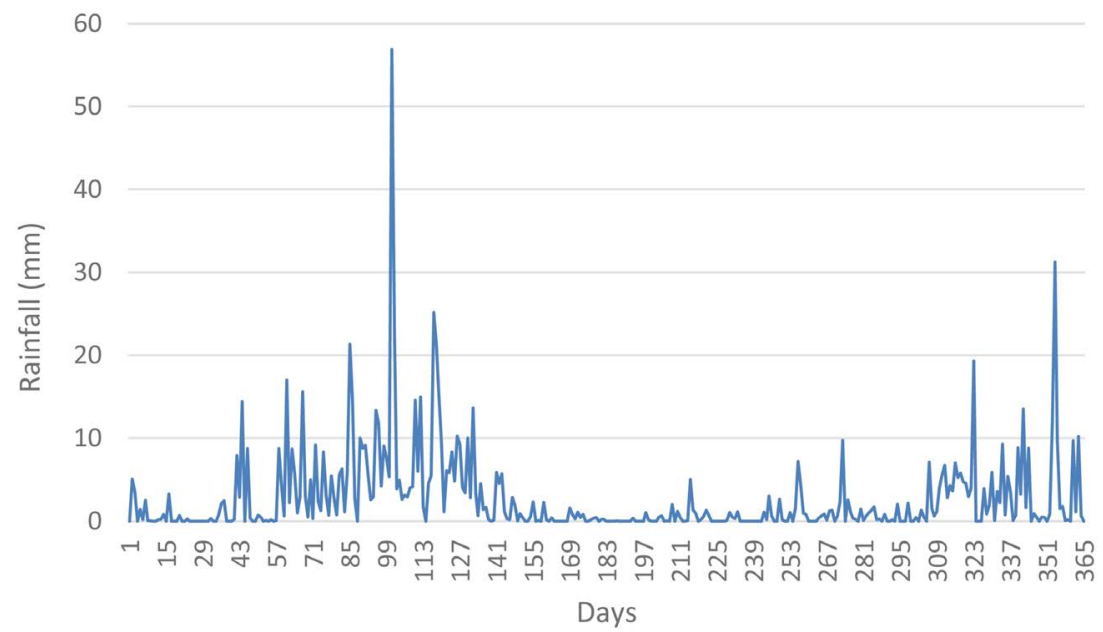

(b)

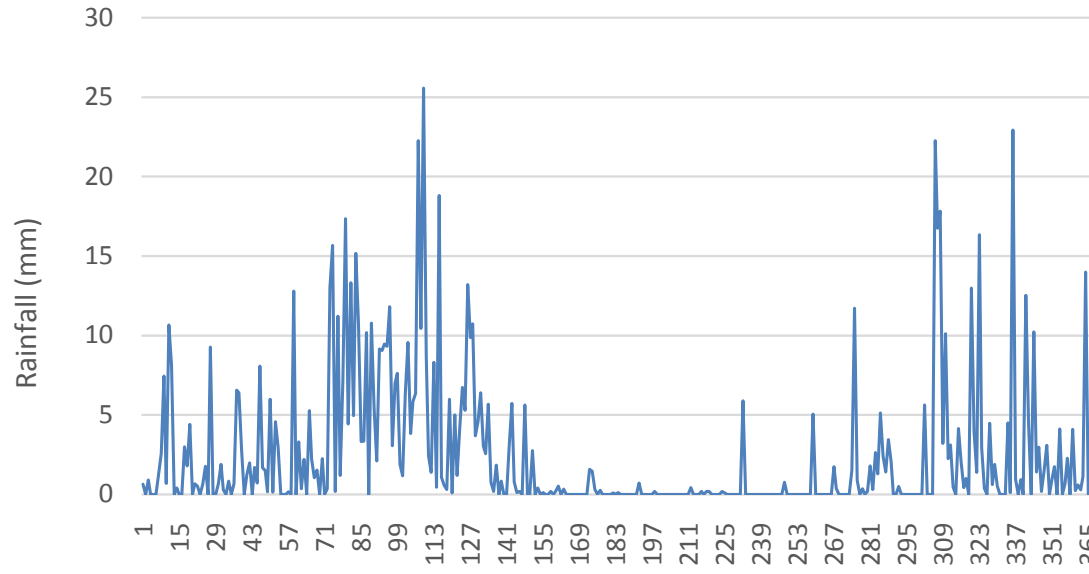

Days

(c)

Figure 2. Average daily rainfall data for the period 2010-2014 for, (a) Mtwara, (b) Dar es Salaam, and (c) Arusha Regions (Source: Tanzania Meteorological Agency). 


\subsection{Rural Household Case Study}

Mtiniko is a village within Mtiniko Ward, which is among 28 wards located within the Mtwara rural LGA in Mtwara Region. Thatched roofs accounts for $80 \%$ of roof types, whereas only $20 \%$ are iron. Individual efforts to address water supply challenges have led to a common practice of constructing open cemented ponds, which collect and store surface water runoff during the rainy season. The collected water is used mainly for domestic purposes.

\subsection{Challenges of Current Water Supply Practice}

Quantity and quality challenges of currently adopted practices affect the economy of the households, limiting opportunities for social empowerment of the village.

\subsubsection{Water Quantity Sufficiency}

Because the pond is open, precipitation falls directly into the pond during the rainy season. Depending on the size of the pond and quantity of rainfall, rainwater loss during the rainy season will be mainly due to overflow only, whereas during the dry season, in addition to daily consumption, losses from evaporation are significant. Annual evaporation in the country is estimated at $2000 \mathrm{~mm}$ [19], which if divided equally among the 117 dry days of an average year (Figure 1(a)), is approximately $17 \mathrm{~mm}$. A low runoff coefficient of at most $50 \%$, due to seepage into the catchment, further reduces quantity harvested from a given rainfall.

\subsubsection{Basic Condition}

The daily water balance model, with modifications incorporating evaporation losses in case of an open pond, was applied to assess the pond performance during the year under fixed demand conditions. The following were basic conditions: population, 5; catchment size, $150 \mathrm{~m}^{2}$; pond area, $12.6 \mathrm{~m}^{2}$; and volume, $20 \mathrm{~m}^{3}$. Evaporation was considered significant for those days when rainfall $\leq 2 \mathrm{~mm}$ and the $C$ is 0.5 .

\subsubsection{Analysis Feedback}

Figure 3 illustrates the current pond performance. The lowest NWD is 70 NWD which is at a lower demand of $100 \mathrm{~L} / \mathrm{d}$ and corresponds to $41 \%$ RUR.

\subsubsection{Water Quality Concern}

Algal growth was an obvious challenge at one site in Mtiniko village. This may have been promoted by the openness of the pond, exposing it to the sun and nutrients from the surroundings, which could easily find their way into the pond through wind effect and runoff from rainfall. Means of accessing water by users is through dipping bucket. The samples were collected and analyzed (within 2013 and 2014) for physical, chemical, and microbiological quality at the Mtwara Zonal and University of Dar es Salaam Water Quality Laboratory. Based on water quality results (Table 1), the pond at Mtiniko village failed the color test and had high total coliform counts, which were also measured in the samples from the other two villages. 


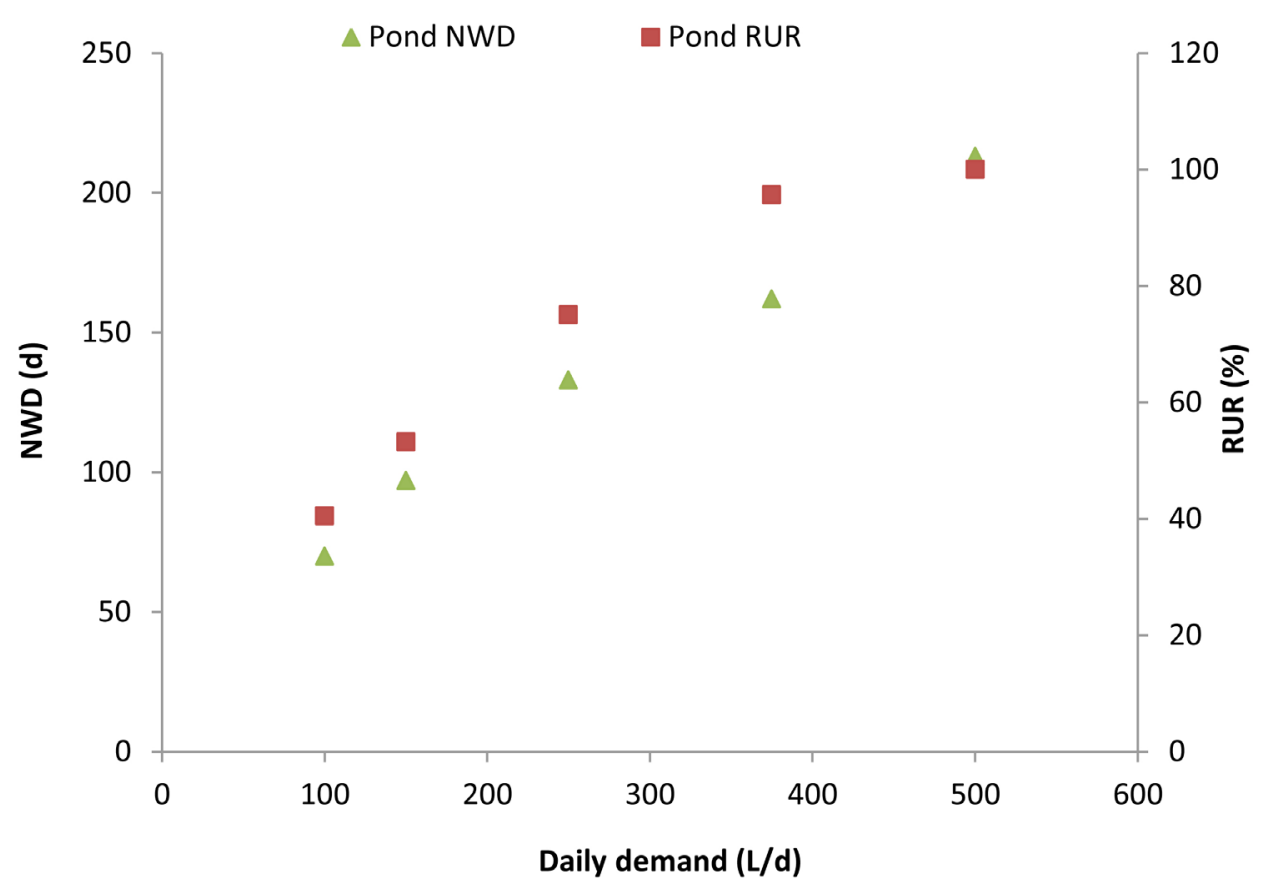

Figure 3. Performance of an open pond under fixed demand conditions.

Table 1. Water quality test results for samples from relied water sources within Mtwara District.

\begin{tabular}{|c|c|c|c|c|c|c|}
\hline \multirow[t]{2}{*}{$\mathrm{S} / \mathrm{N}$} & \multirow[t]{2}{*}{ Parameter } & \multicolumn{3}{|c|}{ Sampling Villages (source type) } & \multicolumn{2}{|c|}{ Standards } \\
\hline & & $\begin{array}{l}\text { Mtiniko } \\
\text { (Pond) }\end{array}$ & $\begin{array}{c}\text { Dinyecha } \\
\text { (RWH tank) }\end{array}$ & $\begin{array}{c}\text { Nanguruwe } \\
\text { (Pond) }\end{array}$ & $\mathrm{TZ}$ & WHO \\
\hline 1 & $\mathrm{pH}$ & 6.56 & 8.5 & 5.75 & $6.50-8.50$ & $6.5-8.5$ \\
\hline 2 & $\begin{array}{l}\text { Total Dissolved } \\
\text { Solids (mg/l) }\end{array}$ & 90 & 75.7 & 72.6 & 1000 & 1000 \\
\hline 3 & Colour (Pt.Co) & 24 & 0 & 7 & 15 & 15 \\
\hline 4 & $\begin{array}{l}\text { Total Hardness } \\
(\mathrm{mg} / \mathrm{l}) \text { as } \mathrm{CaCO}_{3}\end{array}$ & 30 & 8.1 & 5.6 & 500 & 200 \\
\hline 5 & Sulphate (mg/l) & 13 & 1 & 24 & 400 & 500 \\
\hline 6 & Chloride (mg/l) & 5.0 & 2.72 & 25.45 & 250 & $200-300$ \\
\hline 7 & Sodium (mg/l) & 2.6 & 0 & 1.2 & 200 & 200 \\
\hline 8 & $\begin{array}{l}\text { Faecal coliform } \\
\text { (No./100 mls) }\end{array}$ & $\begin{array}{l}\text { Not } \\
\text { tested }\end{array}$ & 11 & 37 & Nil & Nil \\
\hline 9 & $\begin{array}{l}\text { Total Coliform } \\
\text { (No./100 mls) }\end{array}$ & 165 & 27 & 270 & Nil & Nil \\
\hline
\end{tabular}

\subsubsection{Strategies for Improving Water Supply Practice}

For ensuring sufficient demand satisfaction, not only is pond covering recommended but having a simple rooftop RWH system is as well. These can be relied on in a dual manner, with drinking water taken from the RWH system and pond water used for nonpotable purposes to address quality concerns (Figure 4). RWH systems are a possibility as most households in this village had at least one building with an iron roof, even 


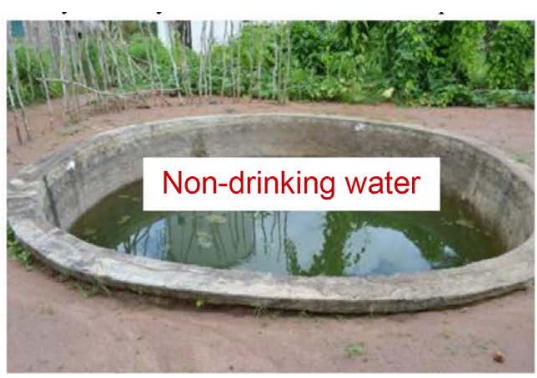

Runoff collection into pond

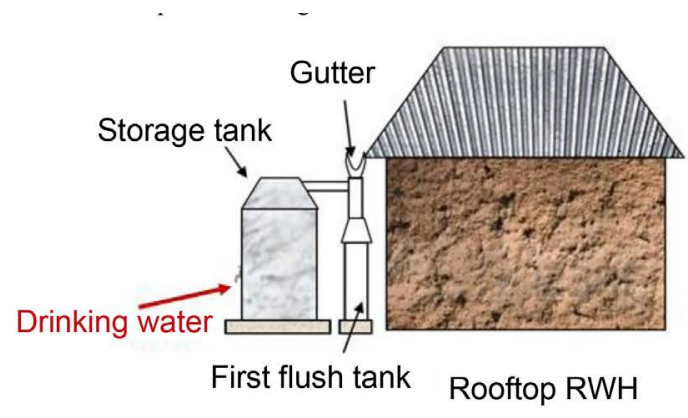

First flush tank Rooftop RWH

Figure 4. Proposed reliance on both surface and rooftop rainwater runoff collection.

if the walls were made of clay. Locally available materials such palm tree can be used in pond covering.

Further analysis was performed to establish a good application strategy. Basic conditions for rooftop case included, roof size of $18 \mathrm{~m}^{2}$ with a runoff coefficient of 0.8 . The storage capacities assessed were $0.5,1,1.5,2.2$, and $3.2 \mathrm{~m}^{3}$ for a population of 5 . Variable daily demand scenarios considered are shown in Table 2 .

Scenario 1 offers better covered pond performance with NWD, and RUR values of zero d, and 58\%, respectively (Figure 5(a)). For rooftop harvesting, Scenario 3 showed better performance with RUR above 50\%. Considering increased storage size results in increased construction cost regardless of the type of material used, therefore, $2.2 \mathrm{~m}^{3}$ is the optimal solution. This storage capacity results in zero NWD and a RUR of $54 \%$ under Scenario 3 (Figure 5(b)).

For total demand satisfaction throughout the year, both harvesting techniques can be adopted to work as a dual water supply. Figure 6(a) shows that during the rainy season the locals can rely on rooftop water for both drinking and cooking with up to $37.5 \mathrm{~L} / \mathrm{d}$, whereas during the dry season, it would only be used for drinking purposes at $10 \mathrm{~L} / \mathrm{d}$. During the rainy season, the pond (Figure 6(b)) can source up to $150 \mathrm{~L} / \mathrm{d}$ of water for meeting household demands other than drinking, but during the dry season the usage would be limited to $100 \mathrm{~L} / \mathrm{d}$. This combination strategy assure the locals that even on dry days there should be at least 2 and $20 \mathrm{~L} /$ person/d for drinking and nondrinking purposes, respectively.

\section{Strategies for Water Supply Practice with RWH in Tanzanian Regions}

The national water sector development strategy [20] on the service level has aims to provide a minimum of $70 \mathrm{~L} /$ person/d for consumers with household connections to a water supply system. Analysis considered household cases in three regions, Mtwara, Arusha and Dar es Salaam (DSM). Arusha and DSM regions are located in the northern and southeastern part of the country, respectively (Figure 1). Basic conditions included, population, 5 (average country household size); rooftop size, 60 and $100 \mathrm{~m}^{2}$; runoff coefficient, 0.8; storage size, 5 and $10 \mathrm{~m}^{3}$; and fixed demand, 70 and $100 \mathrm{~L} /$ person/d. Supplement displays percent of annual water demand that would not be met 
Table 2. Variable daily demand scenarios for the pond and rooftop cases.

\begin{tabular}{|c|c|c|c|c|}
\hline \multirow{2}{*}{ Scenarios } & \multicolumn{2}{|c|}{ Pond } & \multicolumn{2}{|c|}{ Roof } \\
\hline & Water level (\%) & Demand (L/d) & Water level (\%) & Demand (L/d) \\
\hline \multirow{2}{*}{1} & $>50$ & 150 & $>50$ & 15 \\
\hline & $\leq 50$ & 100 & $\leq 50$ & 10 \\
\hline \multirow{3}{*}{2} & $>50$ & 200 & $>70$ & 25 \\
\hline & $\leq 50$ & 100 & $\leq 70$ and $>30$ & 15 \\
\hline & & & $\leq 30$ & 10 \\
\hline \multirow{4}{*}{3} & $>70$ & 375 & $>75$ & 37.5 \\
\hline & $\leq 70$ and $>30$ & 250 & $\leq 75$ and $>50$ & 25 \\
\hline & $\leq 30$ & 150 & $\leq 50$ and $>25$ & 15 \\
\hline & & & $\leq 25$ & 10 \\
\hline
\end{tabular}

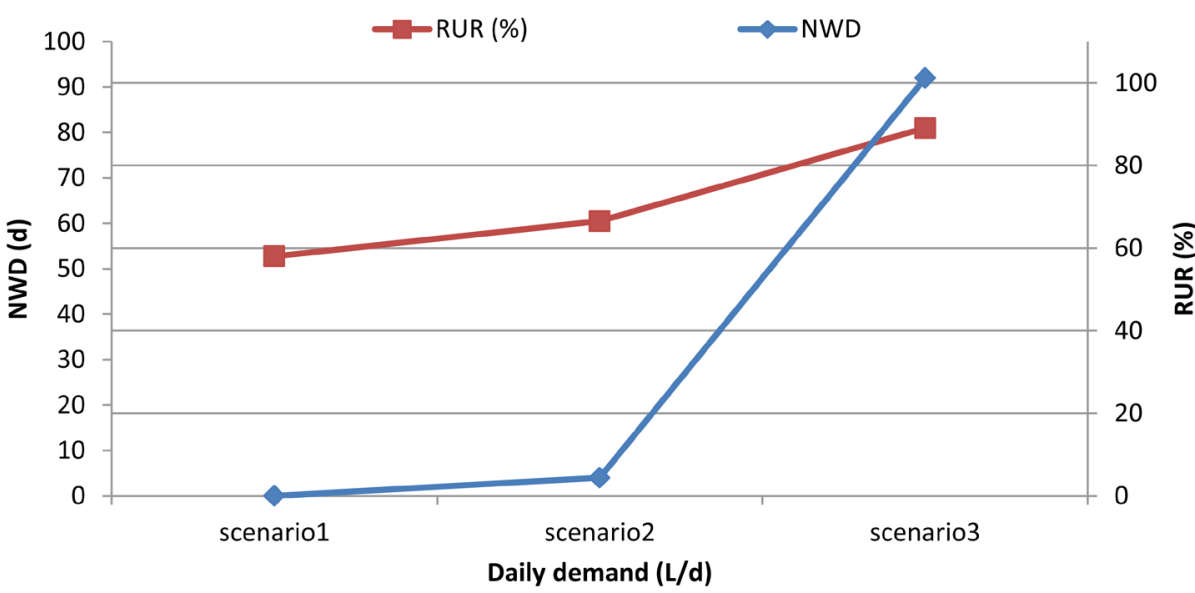

(a)

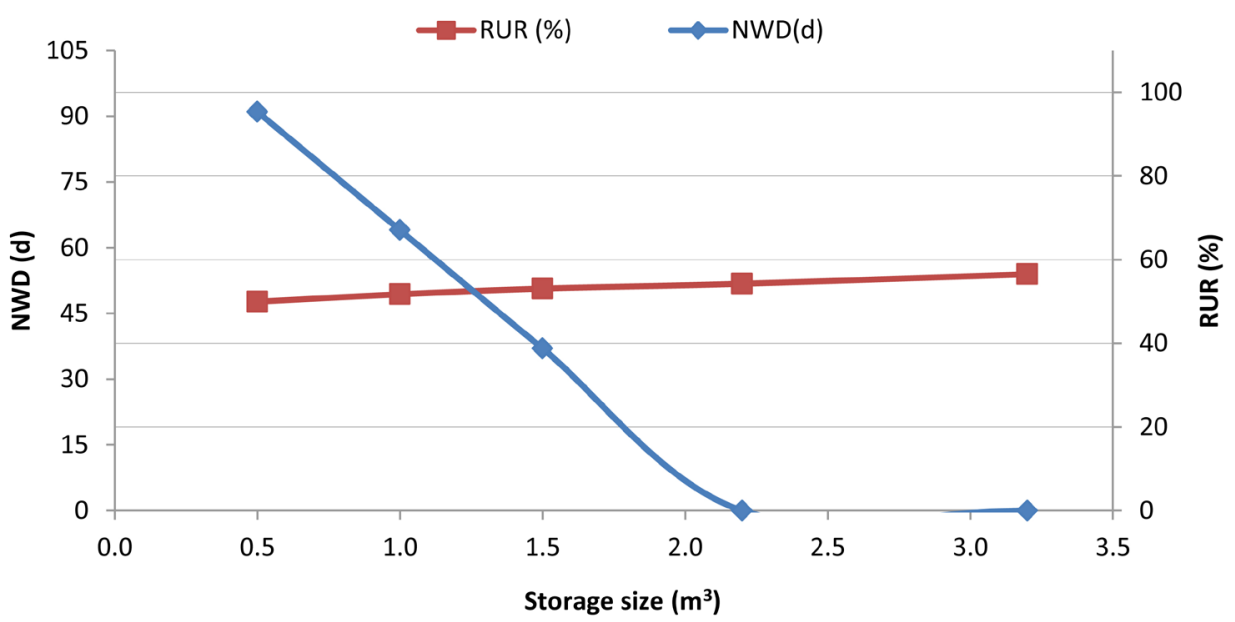

(b)

Figure 5. Performance of (a) covered pond, and (b) rooftop harvesting, systems in variable demand. 


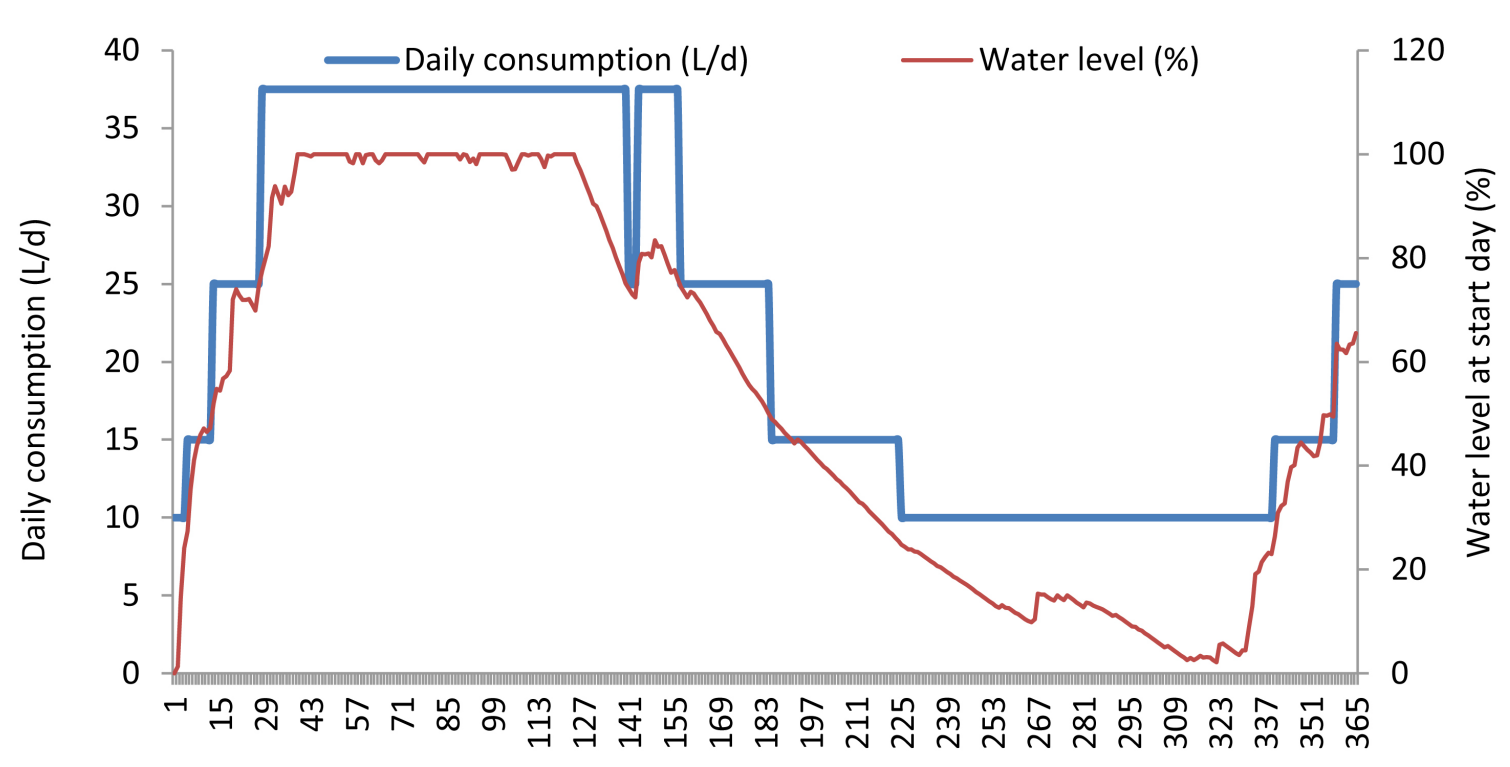

Days in a year

(a)

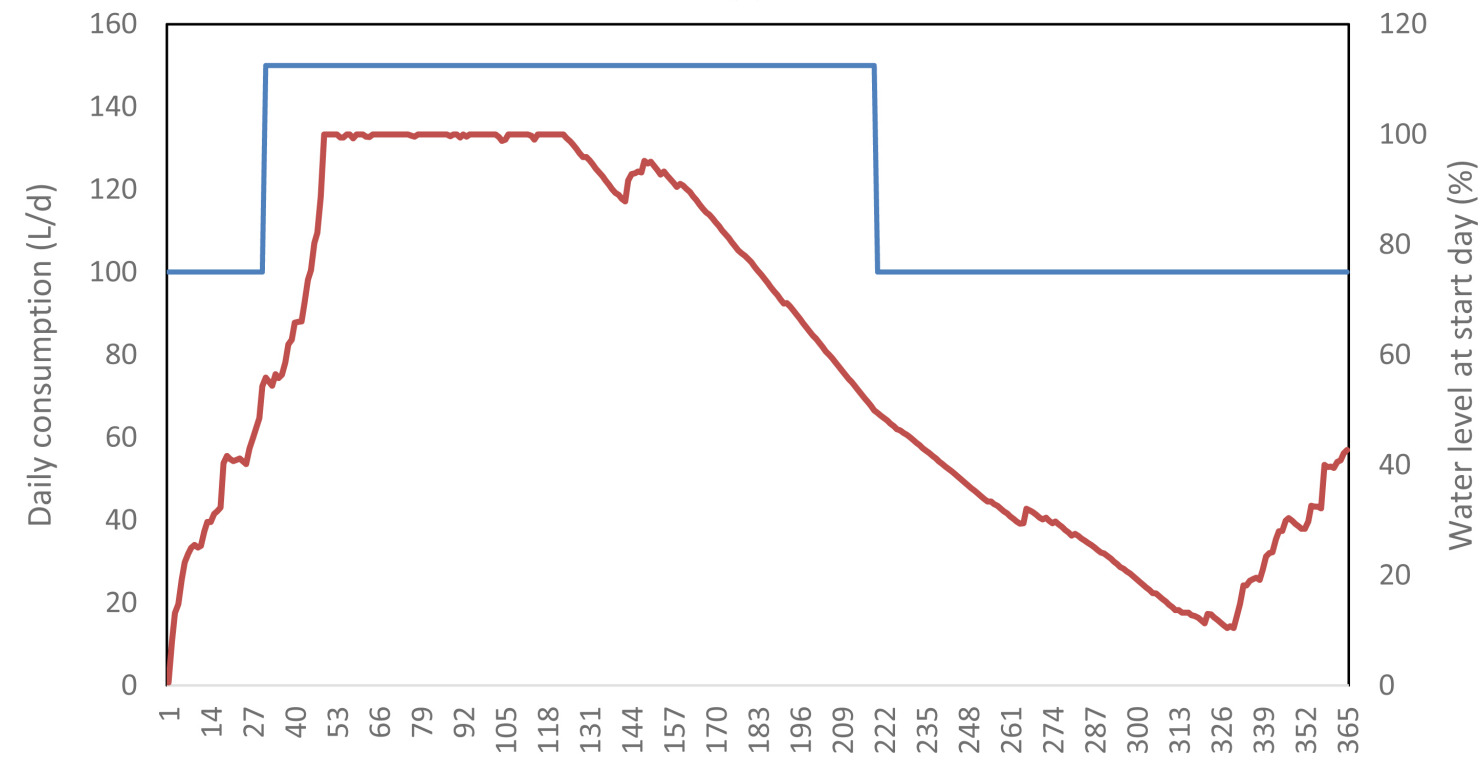

Days in a year

(b)

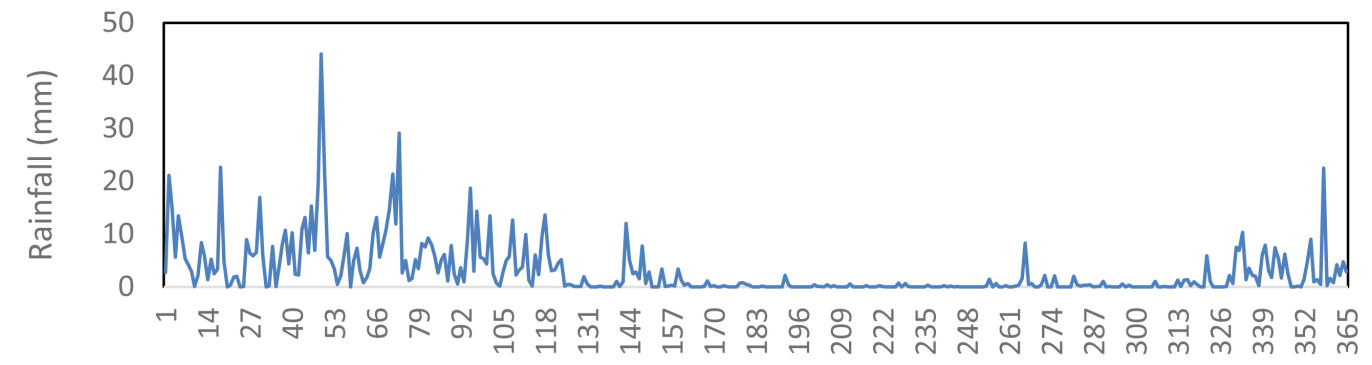

Days

Figure 6. Recommended daily consumption in combined rooftop (a) and surface (b) runoff harvesting. 
through RWH, hence demanding alternative sources.

Amount and variation in rainfall impacts on quantity available for meeting demand (Table 3). Mtwara (even though under unimodal rainfall regime), having highest average annual rainfall has lowest NWD and supplement requirement. Further, at limited catchment, increased storage may have no impact on NWD or RUR e.g., $60 \mathrm{~m}^{2}$.

Moreover, increased catchment implies increased harvestable quantity (Table 3). With same storage, higher reduction of NWD although with slight decrease of RUR e.g., DSM at $5 \mathrm{~m}^{3}$ where number of NWD reduction is equivalent to 2 months. As well, increased storage is required for achieving higher RUR in case the same demand is maintained, e.g., at DSM there is $6 \%$ increase in RUR with $10 \mathrm{~m}^{3}$ at $70 \mathrm{~L} /$ person/d. But same storage can be maintained for increased demand relative to catchment size e.g., DSM there is a difference of $1 \%$ RUR between the two catchment sizes at $10 \mathrm{~m}^{3}$. Generally, with $60 \mathrm{~m}^{2}$ over $23 \%$ of annual demand can be met (at least 1.2 months are fully served), and in $100 \mathrm{~m}^{2}$ over $38 \%$ of annual demand can be met (at least 3.5 months are fully served).

Rainwater catchment increase has greater impact on meeting a specified demand under given condition of rainfall quantity and variation (Figure 7). RWH is capable of reducing the stress of water shortage in both urban and rural areas. Additional sources can supplement rainwater especially in dry season to maintain the desired demand, hence dual system.

Self-financing initiatives should be introduced and promoted including microfinancing, to empower citizens to address own water challenges with RWH. Government should offer incentives, subsidies for those taking responsibility in addressing own water challenges. Increased training on alternative water supply sources e.g., RWH,

Table 3. Performance variation of rainwater harvesting system in the selected regions of Tanzania.

\begin{tabular}{|c|c|c|c|c|c|c|c|c|}
\hline \multirow{2}{*}{$\begin{array}{c}\text { Demand } \\
\text { (L/d) }\end{array}$} & \multirow{2}{*}{$\begin{array}{c}\text { Storage } \\
\left(\mathrm{m}^{3}\right)\end{array}$} & \multirow[b]{2}{*}{ Regions } & \multicolumn{3}{|c|}{ Roof area- $60 \mathrm{~m}^{2}$} & \multicolumn{3}{|c|}{ Roof area-100 $\mathrm{m}^{2}$} \\
\hline & & & $\begin{array}{l}\text { NWD } \\
\text { (d) }\end{array}$ & $\begin{array}{c}\text { RUR } \\
(\%)\end{array}$ & $\begin{array}{c}\text { Supplement } \\
(\%)\end{array}$ & $\begin{array}{l}\text { NWD } \\
\text { (d) }\end{array}$ & $\begin{array}{c}\text { RUR } \\
(\%)\end{array}$ & $\begin{array}{l}\text { Supplement } \\
(\%)\end{array}$ \\
\hline \multirow{6}{*}{70} & \multirow{3}{*}{5} & DSM & 273 & 100 & 63 & 208 & 81 & 50 \\
\hline & & Mtwara & 250 & 100 & 60 & 192 & 78 & 48 \\
\hline & & Arusha & 280 & 100 & 67 & 214 & 87 & 52 \\
\hline & \multirow{3}{*}{10} & DSM & 273 & 100 & 63 & 193 & 87 & 46 \\
\hline & & Mtwara & 250 & 100 & 60 & 175 & 84 & 44 \\
\hline & & Arusha & 280 & 100 & 67 & 199 & 94 & 48 \\
\hline \multirow{6}{*}{100} & \multirow{3}{*}{5} & DSM & 325 & 100 & 74 & 260 & 93 & 60 \\
\hline & & Mtwara & 319 & 100 & 72 & 229 & 94 & 56 \\
\hline & & Arusha & 328 & 100 & 77 & 259 & 98 & 62 \\
\hline & \multirow{3}{*}{10} & DSM & 325 & 100 & 74 & 249 & 99 & 57 \\
\hline & & Mtwara & 319 & 100 & 72 & 219 & 100 & 54 \\
\hline & & Arusha & 328 & 100 & 77 & 255 & 100 & 61 \\
\hline
\end{tabular}



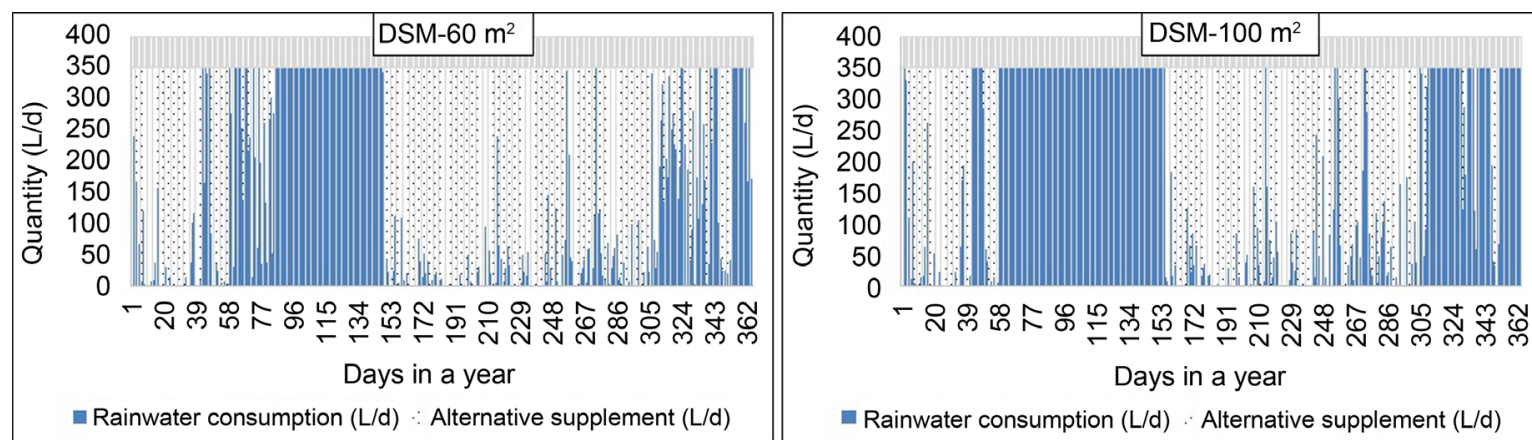

Days in a year

- Rainwater consumption (L/d) Alternative supplement (L/d)
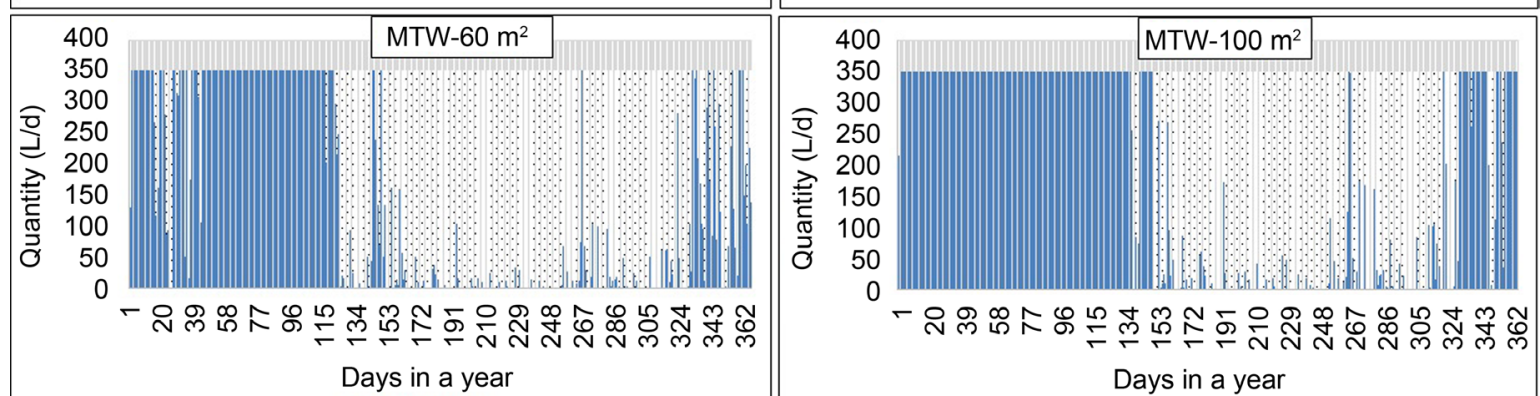

@ Rainwater consumption (L/d) : Alternative supplement (L/d)

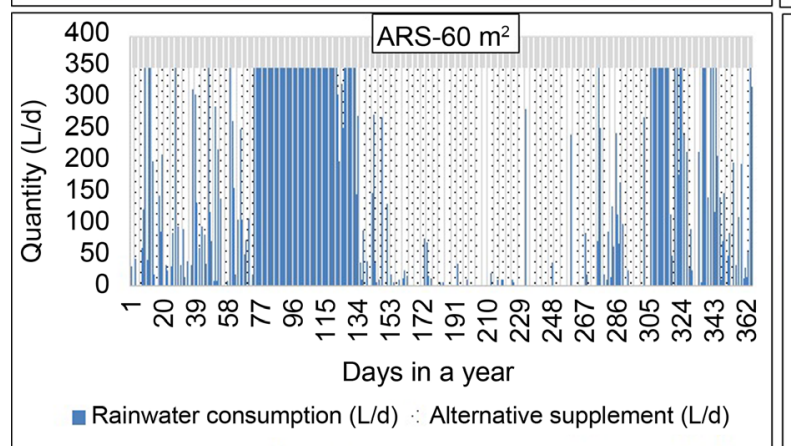

Rainwater consumption (L/d) $\because$ Alternative supplement $(\mathrm{L} / \mathrm{d})$

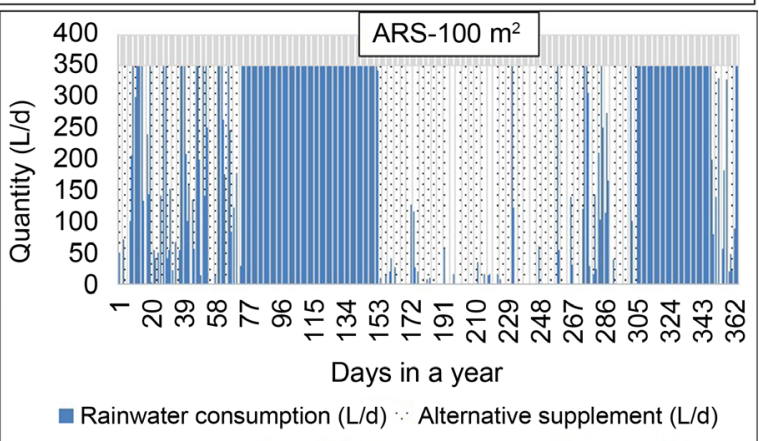

Figure 7. Rainwater consumption and supplement required at different catchment size in the selected regions at 70 L/person/d with $5 \mathrm{~m}^{3}$.

through demo projects, media, village meetings, and with national guidelines established for consistency in application [21].

\section{Conclusions}

Rainwater may not necessarily serve as the sole water source, but it can be useful under dual supply conditions, with other water supplies including surface and GW sources. Having multiple convenient water sources boosts the household water supply self-sufficiency, as was established for the case of Mtiniko village with rooftop RWH. Rainwater catchment increase has greater impact on meeting a specified demand under given condition of rainfall quantity and variation. In terms of quality, rainwater can be prioritized as a drinking water source under dual supply conditions.

In developing countries, available indigenous water supply approaches can be studied, evaluated and improved upon to ensure sufficient and good quality water. These would include crude water harvesting practices. RWH is recommended as a sustainable 
water supply technology, and governments should invest in empowering individuals to address their own water supply challenges with this technology through increased awareness, incentives, and technical and financial support strategies.

This study has offered replicable strategies in addressing household water supply challenges with respect to local conditions of any given developing country.

\section{Acknowledgements}

This research was supported by Korea Ministry of Environment as Eco-Innovation Project (413-111-008). The authors also acknowledge the partial financial support of KSCE and IRICEE for the demonstration project, and the involvement of the Mtwara District Office in Tanzania.

\section{References}

[1] MoW (2014) The Water Sector Status Report 2014, Marking the End of Water Sector Development Programme Phase I. Ministry of Water, Tanzania.

[2] NBS (2011) Tanzania National Panel Survey Report (NPS)-Wave 2, 2010-2011. National Bureau of Statistics (NBS), Dar es Salaam, 1-101.

[3] Pmoralg (2010) Monitoring Local Government Sectors and Performance. Prime Minister's Office Regional Administration and Local Government.

[4] MoW (2014) Simple Querying: Water Point Source Type. Water Point Mapping Tanzania. Ministry of Water, Tanzania.

[5] Malesu, M., et al. (2006) Mapping the Potential of Rainwater Harvesting Technologies in Africa: A GIS Overview and Atlas of Development Domains for the Continent and Nine Selected Countries. In: Obanyi, G., Ed., Technical Manual No. 7, World Agroforestry Centre (ICRAF), Nairobi.

[6] Mwamila, T.B., Han, M.Y. and Kum, S. (2016) Sustainability Evaluation of a Primary School Rainwater Demonstration Project in Tanzania. Journal of Water, Sanitation and Hygiene for Development, 6, 447-455. http://dx.doi.org/10.2166/washdev.2016.186

[7] Temesgen, T., et al. (2015) Design and Technical Evaluation of Improved Rainwater Harvesting System on a University Building in Ethiopia. Water Science and Technology: Water Supply. http://dx.doi.org/10.2166/ws.2015.085

[8] Mwamila, T.B., Han, M.Y. and Ndomba, P.M. (2015) Tackling Rainwater Shortages during Dry Seasons Using a Socio-Technical Operational Strategy. Water Science \& Technology. Water Supply, 15, 8. http://dx.doi.org/10.2166/ws.2015.053

[9] Mwamila, T., Han, M. and Ndomba, P. (2016) Performance Evaluation of Rainwater Harvesting System and Strategy for Dry Season Challenge. Journal of Water Practice and Technology.

[10] Han, M.Y. and Mun, J.S. (2007) Particle Behaviour Consideration to Maximize the Settling Capacity of Rainwater Storage Tanks. Water Science and Technology: Water Supply, 56, 7.

[11] Doyle, K.C. (2008) Sizing the First Flush and Its Effect on the Storage Reliability Yield Behaviour of Rainwater Harvesting in Rwanda. MSc Thesis, Civil and Environmental Engineering Department, Massachusetts Institute of Technology.

[12] Amin, M.T. and Han, M.Y. (2011) Improvement of Solar Based Rainwater Disinfection by Using Lemon and Vinegar as Catalysts. Desalination, 276, 9.

http://dx.doi.org/10.1016/j.desal.2011.03.076 
[13] Gikas, G.D. and Tsihrintzis, V.A. (2012) Assessment of Water Quality of First-Flush Roof Runoff and Harvested Rainwater. Journal of Hydrology, 466-467, 115-126. http://dx.doi.org/10.1016/j.jhydrol.2012.08.020

[14] Kim, M., et al. (2012) Impact of the Surface Characteristics of Rainwater Tank Material on Biofilm Development. Water Science \& Technology, 66, 5. http://dx.doi.org/10.2166/wst.2012.245

[15] Amin, M.T., et al. (2013) Effects of Catchment, First Flush, Storage Conditions, and Time on Microbial Quality in Rainwater Harvesting Systems. Water Environment Research, 85, 13. http://dx.doi.org/10.2175/106143013X13706200598433

[16] Coombes, P.J. (2015) Discussion on "Influence of Roofing Materials and Lead Flashing on Rainwater Tank Contamination by Metal” by Magyar M.I., Ladson, A.R., Daiper, C., and Mitchell, V.G. 2014. Australian Journal of Water Resources, 19, 5.

[17] Nijhof, S. and Shrestha, B.R. (2010) Micro-Credit and Rainwater Harvesting. IRC Symposium 2010 Pumps, Pipes and Promises.

[18] Mwamila, T.B. (2016) Rainwater Harvesting Potential and Management Strategies for Sustainable Water Supply in Tanzania. Ph.D. Thesis, Civil and Environmental Engineering Department, Seoul National University, Korea Republic, 168.

[19] Moges, S.A., Katambara, Z. and Bashar, K. (2003) Decision Support System for Estimation of Potential Evapo-Transpiration in Pangani Basin. Physics and Chemistry of the Earth, Parts $A / B / C$, 28, 927-934.

[20] MoWI (2008) National Water Sector Development Strategy-2006 to 2015. Ministry of Water and Irrigation (MoWI), 1-109.

[21] Mwamila, T.B., Mooyoung, H. and Katambara, Z. (2016) Strategy to Overcome Barriers of Rainwater Harvesting, Case Study Tanzania. Geoscience and Environmental Protection, 4, 13-23. http://dx.doi.org/10.4236/gep.2016.49002

Submit or recommend next manuscript to SCIRP and we will provide best service for you:

Accepting pre-submission inquiries through Email, Facebook, LinkedIn, Twitter, etc.

A wide selection of journals (inclusive of 9 subjects, more than 200 journals)

Providing 24-hour high-quality service

User-friendly online submission system

Fair and swift peer-review system

Efficient typesetting and proofreading procedure

Display of the result of downloads and visits, as well as the number of cited articles

Maximum dissemination of your research work

Submit your manuscript at: http://papersubmission.scirp.org/

Or contact gep@scirp.org 